Research Article

\title{
Parents' Considerations Factors in Choosing Elementary School
}

\author{
Muhammad Rizki *, Sutarto Hadi, Sulaiman \\ Master Program of Education Management, Universitas Lambung Mangkurat, Banjarmsin 70123, \\ Indonesia
}

Article history:

Submission May 2020

Revised June 2020

Accepted June 2020

${ }^{*}$ Corresponding author:

E-mail: haurarizki20@gmail.com

\begin{abstract}
Parents always want the best for their children based on their abilities, including education. For this reason, the concept of assimilation in accordance with the wishes of parents is very useful for schools in mapping prospective applicants. The purpose of this study is to identify: a) what factors that considered by students' parents in choosing schools and b) which factors are the most dominant for making decisions in determining schools. This research is a descriptive qualitative research with a multi-site design. Data in this study were collected through observation, in-depth interviews, and documentation. The collected data is then analyzed with an interactive data analysis model consisting of three stages, which are: data reduction, data display, and verification or drawing conclusions. The results of this study indicate that a) the mix factors that are considered by parents in choosing a school are: product, price, location, human resources, and process; and b) the dominant factor being considered by parents in choosing schools, which are products, processes, prices, human resources and location, as well as the foundation of the school's religious philosophy and long-standing positive image. This study recommends that schools that want to increase the number of students should make an increase in the dominant factors into consideration for parents in choosing schools for their children.
\end{abstract}

Keywords: Choosing a school, marketing assimilation, students' parents

\section{Introduction}

With the development of the present arrangement of life, it has an impact on various aspects of life. One of the supports of the development is education. The demand for education is getting higher, where this is due to the increasing desire of parents also for schools as providers of educational services. Schools are continuing to grow and develop, producing a certain competition at each level. Students' parents as the community are the subject in terms of choosing a school. The school chosen by parents is a school that suits their own desires. In general, a quality school graduate as desired by the community is the result of the responsibility of the school organization in accommodating human resources to be well-systemized (Aslamiah, 2015).
Based on national education rules, a good school is a school that is given autonomy and school engagement with stakeholders (Suriansyah, Aslamiah, \& Sulaiman, 2014). Schools which are given autonomy will make it easier for schools to manage available resources, financial and learning support tools, prioritizing things that are deemed necessary for the needs that are indeed appropriate (Suhaimi \& Efendi, 2018). A good school is a school that implements and strives to improve in a positive direction, which is strongly influenced by the quality of the principal's leadership (Suhaimi \& Efendi, 2018). Performance, behavior, and culture as well as the philosophical foundation of an institution greatly affect the quality of education (Suriansyah, 2018). The performance of all human resources in the 
school greatly affects the reputation of the school (Alamsyah, Aslamiah, \& Rizalie, 2019).

The role of the leader or the school is very influential on all aspects of quality in the school. The headmaster should have a skill in managing all available resources to achieve the desired goals (Normianti, Aslamiah, \& Suhaimi, 2019). Then, the party most responsible for the running of a school institution and in the context of achieving success in achieving a goal is the principal or the leader (Suhaimi \& Khalik, 2018).

On the other hand, there are times when the leadership of an institution pays attention to work motivation in the workplace. According to Morgan, motivation is something that is very important in terms of achieving goals (Alamsyah, Aslamiah, \& Rizalie, 2019). Motivation can function to achieve the goals of an institution with various approaches (Normianti, Aslamiah, \& Suhaimi, 2019).

Schools that want to get optimal new students certainly have to think about aspects of the marketing assimilation. Marketing can be described as the process of defining, anticipating, creating, and meeting the needs and desires of consumers for products and services (David, 2011). Marketing service education mix is a 7P concept consisting of: product, price, position, promotion, and people, Physical evidence, and process (Zeithaml, Bitner, \& Gremler, 2013).

Initial observations were made by looking at the data on the number of New Student Admissions (PPDB) of primary schools equivalent under the auspices of the Muhammadiyah Elementary and Secondary Education Board (Dikdasmen) in the city of Banjarmasin, where there were two schools studied, MDIM 1-2 Sei. Kindaung Banjarmasin and SD Muhammadiyah 9 Banjarmasin. Preliminary observations indicate something different in terms of business related to increasing acceptance of new students. So that it has an impact on the segmentation and factors behind the parents of students in choosing a school.

A marketing concept map is needed to find out what factors are considered by parents of students in choosing a school. Improvement and ability to maintain the number of New Student Admissions is done each year at MDIM 1-
2 Sei. Kindaung Banjarmasin and SD Muhammadiyah 9 Banjarmasin that were studied became an interesting phenomenon.

The purpose of this study is to describe the factors which are considered by students' parents in general in choosing a school and describe the factors which are dominant considerations of parents in choosing a school.

Information on what factors are considered by students' parents in choosing a school is needed to increase what is needed and reduce or eliminate anything that does not support school progress. In general, the mapping concept of the marketing services marketing mix is to find out and improve school curricula and programs that are in accordance with the wishes of the community. In addition, by knowing the wants and needs of parents, the school can determine the appropriate policy in winning the market, which makes the school the first choice for students' parents (Ertas, 2013).

\section{Material and Methods}

The research approach used by researchers is a descriptive qualitative. This method is considered as a relevant in the formulation of problems that require writers to conduct critical studies to explain and understand through intensive relationships with sources of data. As stated by Moleong (2007) that qualitative research intends to understand phenomena about what is experienced by research subjects such as behavior, perception, motivation, action, etc. holistically, and by means of descriptions in the form of words and language in a special natural context and by utilizing various natural methods.

The design of a multi-case study was carried out to hold scientific responsibility in relation to the logical relationship between the focus of research, collection, and analysis of relevant data. This is a multi-case study conducted at MDIM 1-2 Sei, Kindaung Banjarmasin and SD Muhammadiyah 9 Banjarmasin. Both institutions have increased and the ability to maintain the number of New Student Admissions is almost every new school year. Data sources included the principal, chairman of the foundation, chair of the Banjarmasin City Elementary and Secondary Education Assembly and students' parents. 
In this study data collection was carried out observation, in-depth interviews, and documentation. The collected data is then analyzed with an interactive data analysis model consisting of three stages, namely: data reduction, data display, and verification or conclusion drawing.

\section{Results and Discussion Product Factor}

In this study, researchers found various kinds of considerations of students' parents in choosing a school, of which this product factor was the most dominant factor affecting parents. If a school pays attention to this, it is possible that it will be easy to bring in registrants at each Admission of New Students per year.

Schools that are chosen by many parents regarding product factors are schools that have a strong philosophical foundation, a good school reputation and have been tested for a long time, products that can compete with superior schools, products that can be accepted in top schools and schools that have something that is compatible with what the community's demand.

Each school must have its own philosophical foundation. This is transformed into a character that is seen in the attitudes and behavior of the school in each of its activities and policies. The philosophical foundation in the school studied here leads to a lot of philosophies of positive religious values, where the majority of people in Banjarmasin are very close to strong religious activities. The strength of the existing school philosophy if it produces results in the form of a number of reputations will certainly become an added value that is owned by the school.

Schools that are targeted by parents are schools that are able to compete with other schools in terms of producing products (students) that are superior and easy to be accepted in superior destination schools. This is widely seen from the data of destination schools (Islamic Secondary School, State Secondary School, Private Secondary School and famous Islamic boarding schools) which were successfully entered by students from these two schools. The school that presents all the needs of parents of students will be easier to bring in parents who enroll their children. MDIM 1-2 Sei, Kindaung Banjarmasin is a school that tries to present a modern madrasa education, where academic and religious education is taught in the latest (the age) and the most preferred parents are students in every activity the teacher always instills positive religious values in accordance with what is desired by the students' parents. Whereas at SD Muhammadiyah 9 Banjarmasin, schools try to present academic and religious education that is no less competitive with more expensive schools around Banjarmasin at prices that are affordable by most parents of students.

From the explanation above, it can be understood that the quality of the products offered by schools is an important factor for consideration by parents. The same research results were also found by Suppramaniam, Kularajasingam, \& Sharmin (2019) who found that Parents in Bangladesh also who found that Parents in Bangladesh also took into account the quality of the school as the basis for selecting schools for their children. The quality of the school in question is whether the school can produce students who excel and whether after graduating they can easily proceed to a superior school.

\section{Price Factor}

Based on the data found, related to the price of the opinions of parents in the two schools studied became a dominant factor in influencing parents in choosing a school. MDIM 1-2 Sei. Kindaung Banjarmasin and SD Muhammadiyah 9 Banjarmasin in terms of payment almost have in common, which is suitable for the lower middle class. Many parents think that schools are very accommodating in terms of prices so they can be cheaper with quality that is not inferior to schools that charge higher prices. And there are some parents of students who think that the quality of education of the two schools exceeds other superior schools. As a result there are many students' parents who feel that they made a right choice.

The price factor is undeniably very important to attract the attention of people to choose a school. Not only for elementary edu- 
cation level, even for secondary and higher education level. As happened in Sub-Saharan Africa, free school fees can attract parents and students to enroll to higher education (Koski, et al., 2018). Conversely an increase in tuition fees could have an impact on decreasing the number of students who continue their studies (Hemelt \& Marcotte, 2011). The cost of education proves to be very important for students and parents in determining the school, as happened in Qatar where prospective students make education costs a crucial consideration (Mustafa et al., 2018). Even something similar happened in the UK, an increase in the cost of education also resulted in a decrease in the number of students who continued their studies to University (Wilkins, Shams, \& Huisman, 2013).

\section{Location Factor}

For location factors, the two schools have many similarities, such as 1) located in the middle of the city, 2) located in a narrow alley and 3) near a densely populated settlement. Even so the existence of parents is not too concerned about these things, because the most important is the location of the school is still easy to access for transportation between two-wheeled vehicles and environmental conditions that are safe and conducive. For parents at MDIM 1-2 Sei, Kindaung Banjarmasin, location factor is not dominant, but for parents at SD Muhammadiyah 9 Banjarmasin location is the dominant factor in choosing schools.

At SD Muhammadiyah 9 Banjarmasin, the location of the school is in a narrow alley and in the middle of a densely populated settlement. But the added value of this school is that the school is located in the middle of the city of Banjarmasin (the main street of the city), so it is very strategic to become a school that wants to position itself as a superior school and can have an impact on bringing the number of participants New Student Admissions to increase dynamically every year.

The location that facilitates access to transportation is one of the considerations which are taken into account by parents in choosing a school for their children (Sharma \& Tripathi, 2016). The easier access is, the easier students will go to school either transfer by their parents or departing using public transportation. However, if viewed from the side whether the location of the school affects learning achievement, the results of research conducted by Ntibi \& Edoho (2017) found that there was no difference in learning achievement caused by differences in school locations. Therefore, it can be said that the location of the school is only a consideration in terms of accessibility.

\section{Promotion Factor}

Among all the factors that exist, the promotion factor carried out directly is a factor that is not dominant for parents in choosing a school. Among the many interview data findings and documentation of the New Student Admission registration form, many parents who choose schools are influenced by indirect promotion. The indirect promotion means the parents of students who directly look directly into the products of a school (the results of the students 'and academics' formation). This is the main thing parents want.

MDIM 1-2 Sei, Kindaung Banjarmasin and SD Muhammadiyah 9 Banjarmasin in the past few years have done many direct promotions, for example 1) coming directly to the targeted Kindergartens 2) installing banners at various strategic points 3) distributing brochures in strategic places etc., but has little impact on increasing the number of registrants.

The product of a service company may be wrong consumers in choosing one time, but parents of students in choosing a school do not want to wrong in choosing a school. Moreover, those parents who enroll their children in private schools for more than public primary schools are parents who really want something that is better for their children.

The purpose of the promotion is to make the school known. By being known by the community, it will be able to build public confidence that the school is categorized as a good school, because one indicator that the school is good is well known in the community (RicoBriones \& Bueno, 2019). Famous which is referred here is having a good academic reputation, because a school that has a good reputation will be able to attract the attention of parents (Bosetti, 2004). 


\section{Human Resource Factors (HR)}

Human resource factor (HR), for parents at MDIM 1-2 Sei, Kindaung Banjarmasin is indeed very dominant in influence, whereas for parents in SD Muhammadiyah 9 Banjarmasin is not dominant in influencing when choosing a school.

There are a number of findings related to HR in MDIM 1-2 Sei, Kindaung Banjarmasin, which made many parents choose this school, such as 1) the school has role models who have close and wide family and community relations, 2) leaders who are also active in socio-religious organizations and 3) teachers and education personnel who are indeed famous for educating a strong philosophical foundation by the school. These 3 (three) things very much influence the parents' interest in choosing this school for their children.

The quality of teaching staff will affect student achievement. As found by Darling-Hammond (2000) that improving teacher quality has implications for increasing student achievement. Even the quality of teachers does not only affect the ability of students in academic matters, but also is proven able to shape the attitudes and behavior of students (Blazar \& Kraft, 2017). Positive things from a teacher will have a positive effect on students. Like for example, the enthusiasm of teachers in teaching will affect student activity in the learning process (Mahler, Großschedl, \& Harms, 2018). Likewise with teacher communication, good communication between teacher and students both verbal and non-verbal will affect the mood of students while learning and subsequently will have implications for their learning outcomes (Bambaeeroo \& Shokrpour, 2017).

Neither on the contrary, if the teacher is not motivated to teach it will negatively affects student motivation and learning outcomes (Shen, et al., 2015). In addition, the way teachers' pay attention to students in class is also proven to affect student learning achievement, teachers who are able to give proportional attention to students will help students in improving their learning achievement (Kiany \& Shayestefar, 2011). Thus, training to improve teacher quality is very necessary, because through appropriate training the teacher can improve the quality of the learning process which at the same time can improve student achievement (Webster-Stratton, Jamila Reid, \& Stoolmiller, 2008).

Seeing the effect of teacher quality on student achievement and attitudes it is very natural that parents make the quality of teachers one of the considerations in choosing a school for their children. Similar research results were found by Yaacob, Osman, \& Bachok (2015) who found that teacher quality was an important factor for parents in choosing schools for their children.

Unlike the MDIM 1-2 Sei, Kindaung Banjarmasin, SD Muhammadiyah 9 Banjarma-sin, does not emphasize the central figure but on the strength of the attractiveness of human resources in the school as a whole with everything in the school, where parents look at the school not only the attractiveness of the teacher but also all in school. Similar research results were also found by Bosetti (2004) which found that parents chose schools for their children based on the academic reputation of the school which included the reputation of the principal, teachers, staff, and student achievements.

\section{Facilities and Infrastructure Factors}

Similar to the promotion factor, for facilities and infrastructure factors or facilities are not dominant in influencing parents of students in choosing a school. Both schools are indeed schools that are still incomplete in terms of facilities and infrastructure, both for academic activities and other supporting activities. The parents who were met for the two research schools were not concerned with the completeness of the facilities and infrastructure of a school, what they prioritized was the quality of the products and processes in the school. The school always tries to always complement what is still lacking and is indeed needed. Related to this, the school has already established several collaborations with third parties in terms of fulfilling facilities and human resources, for example renting a sports hall, bringing in a drum band trainer, etc. And all of this in the eyes of the parents of students, the school has tried to always try to meet the completeness of facilities and infrastructure. 
However, that does not mean that schools can ignore the supporting facilities for the implementation of learning. Research conducted by Adebayo (2009) found that, for the case in Nigeria, parents made the availability and quality of learning facilities one of the reasons for choosing a school for their son or daughter. The results of the study were also supported by Akhter (2017) which also found that parents in Pakistan made facilities, primarily the use of the latest technology by schools, a consideration in choosing schools.

Facilities as consideration are reasonable; given the existence of learning support facilities will be able to improve student learning achievement (Ramli \& Zain, 2018). This is supported by the results of research conducted by Ibe and Abamuche (2019) who found that the use of audiovisual-based learning media was able to increase students' interest in learning and presenting. Moreover for children of age, the use of technology will make learning more interesting (Baharuddin \& Dalle, 2019). Furthermore, the use of technology also makes learning more effective and flexible because the learning process makes it possible to be done anytime and anywhere (Dalle, Hadi, Baharuddin, \& Hayati, 2017). Likewise with research conducted by Lumpkin, J., Hope, \& Lutfi (2014), who found that the quality of school buildings and their supporting facilities affected student learning achievement. That is because students who feel happy with the look of the school will be proud of the school and have a sense of ownership of the school so they will be happy to go to school (Williams et al., 2018).

Furthermore, the quality of buildings and supporting facilities will affect the comfort; enthusiasm and safety of students in learning so that they can learn well and achieve optimal performance (Cheryan, Ziegler, Plaut, \& Meltzoff, 2014). School safety will be very important in the learning process, with the availability of supporting facilities such as CCTV that can prevent accidents or other safety problems such as fights between students will make the school atmosphere more conducive. Bearing in mind the increasingly widespread cases of violence in schools, the security and order of schools is very much needed to be improved to make the learning process more optimal (Cornell \& Mayer, 2010).

\section{Process Factor}

The process factor is one of the mixed concepts which is one of the dominant factors affecting parents in choosing a school. The process at school becomes the focus of attention that is most prioritized by parents of students, ranging from matters directly related to students or those that are not directly. Here the parents choose the school by paying attention 1) relating to Teaching and Extracurricular Learning Activities and 2) relating to the inculcation of positive values in every process in the school. Positive values here are religious moral values which parents cannot teach at home.

Teaching and extracurricular activities or other activities at school at MDIM 1-2 Sei, Kindaung for parents is very much in accordance with what they want, which is to inculcate religious moral values in accordance with religious teachings and understandings adopted by the majority of parents of students in school. These values are already known by parents of various kinds of information; alumni, family, neighbors and relatives, and is reflected in the daily lives of students who are and or are already attending MDIM 1-2 Sei. Kindaung Banjarmasin. So that most parents want their children to also get teaching and education related to the inculcation of values.

Almost the same as MDIM 1-2 Sei, Kindaung Banjarmasin, SD Muhammadiyah 9 Banjarmasin was chosen by parents because of the process factors in this school. Many parents consider this school capable of educating their children, which is no less competitive with other superior schools around East Banjarmasin, of course at a more affordable price. So that parents consider this school to be very accommodating to the needs of students and parents in terms of religious basic education.

A good learning process will have a positive effect on student achievement. The interaction between teacher and student is one indicator in a good learning process. If the interaction between students and teachers is carried out well there will be a good emotional bond between the teacher and students that makes students feel comfortable when the learning process 
takes place which will then form a conductive learning climate so that it will have an impact on improving learning achievement (Allen, et al., 2013). With the creation of emotional closeness, it will create an active learning atmosphere, because students will feel comfortable in asking questions and delivering the problems they face during the learning process to the teacher (Pöysä, et al., 2019). These results are also supported by research findings Martin and Rimm-Kaufman (2015), that is, a strong emotional connection between teacher and student is able to make students interact more actively in the class, even though they are students with less confidence. In addition to strengthening emotional relationships, teacher and student interactions will form organizational relationships, and a learning culture that is very important in teaching and learning (Hafen, et al., 2015). The culture will further shape the classroom and school climate, which will play an important role in shaping the harmony of the school community, if all school members have close social relations then if there are problems, especially for students, they will soon be able to know and find solutions. (O'Brennana, Bradshawa, \& Furlong, 2014).

The student-centered learning process can also be an indicator that the learning process is well implemented. One example of studentcentered learning is collaborative learning. Collaborative learning is very important to be carried out considering the ability to work together is very necessary in the world of work which is the future of children (Premo, Cavagnetto, Davis, \& Brickman, 2018).

\section{Dominant Factors that Students' Parents Consider in Choosing Schools}

Factors that dominate students' parents' considerations in choosing a school are product, process, price, location and HR. In addition, there were also other factors which became a consideration for parents of students in choosing a school. Among the various findings, at least in general these other factors such as philosophical foundations in religious-based schools where parents consider the school can provide good religious education by also providing general education that can compete with other superior schools (not old-fashioned).

The philosophical foundation of the two schools is considered by parents to have a large spirit and is well defended. Then, it becomes a positive image that can be maintained from generation to generation which makes many parents who know and ultimately choose the school from the recommendations of their extended family who have long been alumni of the two schools. As a result, the philosophical foundation factor and the ability to maintain the school's morale became a supporting factor to the concept of mix that made the two schools eligible to be selected.

The process collectivity will produce school products. MDIM 1-2 Sei. Kindaung Banjarmasin is a school that has been established for a long time since 1921, many achievements have been made by this school both in the academic and religious fields. It is not easy for this school to maintain that reputation. With this reputation, many alumni have sent their children back to school in this school. They alumni want their descendants to get the same education (process). Whereas at SD Muhammadiyah 9 Banjarmasin, parents chose this school because they thought the processes and products produced could compete with superior schools and schools that were more in terms of price. So that schools are considered to be very accommodating for parents who want affordable prices but get good and optimal education for religious and general education. In which that has succeeded in building a positive image in society for a long time.

If simplified, the deciding factor for parents to choose a school for their children is the quality of the school (Maangi, 2014). Parents want to choose the best school for their children, even though the best definition from each parent's side may be different so it cannot be explained in a simple description (Thanerajah \& Razilan, 2017). The definition of quality by parents is usually influenced by their socioeconomic background, i.e. there is a tendency that parents with higher incomes will prioritize schools with high academic reputations as their priorities (Burgess, Greaves, Vignoles, \& Wilson, 2014). 
Table 1. Cross Site Data Analysis

\begin{tabular}{|c|c|c|}
\hline Variable & $\begin{array}{c}\text { Site } 1 \\
\text { MDIM 1-2 Sei. Kindaung Banjarmasin }\end{array}$ & $\begin{array}{c}\text { Site } 2 \\
\text { SD Muhammadiyah } 9 \text { Banjarmasin }\end{array}$ \\
\hline Product Factor & $\begin{array}{l}\text { - The school has a strong philosophical } \\
\text { foundation } \\
\text { Good school reputation (academic } \\
\text { and religious), and many achieve- } \\
\text { ments in various championship } \\
\text { events. } \\
\text { - Products that can compete with other } \\
\text { - } \quad \text { chool graduates } \\
\text { - } \quad \text { Provision of religious knowledge } \\
\text { that is widely accepted by students }\end{array}$ & $\begin{array}{l}\text { - } \text { Good school reputation (academic } \\
\text { and religious) } \\
\text { - } \quad \text { Products that can compete with } \\
\text { other school graduates } \\
\text { - Can be accepted by favorite } \\
\text { schools }\end{array}$ \\
\hline Price Factor & $\begin{array}{l}\text { Schools are considered by parents to be } \\
\text { quality schools but with affordable fees, so } \\
\text { many are chosen by them }\end{array}$ & $\begin{array}{l}\text { With a more reasonable price than a more } \\
\text { expensive school, you can get the same } \\
\text { results and even more. }\end{array}$ \\
\hline Location Factor & $\begin{array}{l}\text { Parents choose schools because of the quality } \\
\text { of products and processes that are difficult to } \\
\text { obtain elsewhere, so even though parents are } \\
\text { far away, they still want to send their children } \\
\text { to school at this school }\end{array}$ & $\begin{array}{l}\text { The school is in the middle of the city, which } \\
\text { makes it easy for parents to pick up their } \\
\text { children. }\end{array}$ \\
\hline $\begin{array}{l}\text { Promotion } \\
\text { Factor }\end{array}$ & $\begin{array}{l}\text { Only a few parents know about acceptance } \\
\text { through promotions. }\end{array}$ & $\begin{array}{l}\text { For parents who really want to send their } \\
\text { children to school in this school are actively } \\
\text { looking for themselves into schools to find } \\
\text { out how the process in a school and see } \\
\text { firsthand from their closest relatives. }\end{array}$ \\
\hline & $\begin{array}{l}\text { - There is a populist leadership figure in } \\
\text { which he has many and extensive kinship, } \\
\text { and he is active in various social and reli- } \\
\text { gious organizations. } \\
\text { Teachers who are widely known by } \\
\text { parents and have kinship in } \\
\text { kindergartens and day care centers } \\
\text { around this school. }\end{array}$ & $\begin{array}{l}\text { Many parents of students who see from the } \\
\text { products and processes in this school } \\
\text { collectively from all aspects of support in } \\
\text { the school }\end{array}$ \\
\hline Facility Factor & $\begin{array}{l}\text { Parents are more concerned with the quality } \\
\text { of products and processes. }\end{array}$ & $\begin{array}{l}\text { Parents are more concerned with the quality } \\
\text { of products and processes. }\end{array}$ \\
\hline Process Factor & $\begin{array}{l}\text { Parents are very concerned about all activities } \\
\text { in the school such as; Teaching and learning } \\
\text { activities, extracurriculars, and what parents } \\
\text { want most is the process of inculcating } \\
\text { positive values in all existing activities and } \\
\text { that is found by parents in this school. }\end{array}$ & $\begin{array}{l}\text { Parents are very concerned about all } \\
\text { activities in the school such as; Teaching and } \\
\text { learning activities, extracurriculars, and } \\
\text { what parents want most is the process of } \\
\text { inculcating positive values in all existing } \\
\text { activities and that is found by parents in this } \\
\text { school. }\end{array}$ \\
\hline $\begin{array}{l}\text { Other } \\
\text { Consideration } \\
\text { Factors }\end{array}$ & $\begin{array}{l}\text { The philosophy and school spirit that can be } \\
\text { maintained from generation to generation }\end{array}$ & $\begin{array}{l}\text { The positive image of the school is } \\
\text { generated from the reputation and products } \\
\text { of the school }\end{array}$ \\
\hline
\end{tabular}


Table 2. Cross Site Findings

\begin{tabular}{|c|c|}
\hline Variable & $\begin{array}{l}\text { Cross-Site Research Findings Factors of Students' Parents' Considerations in Choosing } \\
\text { Schools }\end{array}$ \\
\hline Product Factor & $\begin{array}{l}\text { Students' parents in choosing schools with consideration: } \\
\text { - School reputation } \\
\text { - School students and alumni can compete with other schools } \\
\text { - Can be accepted in top schools }\end{array}$ \\
\hline Price Factor & $\begin{array}{l}\text { Parents of students choose schools with consideration that if there are schools with more af- } \\
\text { fordable prices and the same quality as more expensive schools, then cheaper schools are pre- } \\
\text { ferred }\end{array}$ \\
\hline Location Factor & $\begin{array}{l}\text { Students' parents choose location-related schools with consideration: } \\
\text { - Make it easier for parents to pick up and drop } \\
\text { - safe and conducive environment }\end{array}$ \\
\hline Promotion Factor & $\begin{array}{l}\text { Students' parents choose schools through indirect promotion, which is through the processes } \\
\text { and products of the school that are seen directly by the community. }\end{array}$ \\
\hline HR Factor & $\begin{array}{l}\text { Regarding HR, parents chose the school with consideration: } \\
\text { - There is a figure (teacher) in the school who has the ability to establish close and wide } \\
\text { relationships in the community } \\
\text { - Teachers who truly protect students sincerely in delivering positive values }\end{array}$ \\
\hline Facility Factor & $\begin{array}{l}\text { Students' parents choosing schools do not pay much attention to the facilities provided by the } \\
\text { school }\end{array}$ \\
\hline Process Factor & $\begin{array}{l}\text { Students' parents choose schools with consideration of teaching and learning activities, extra- } \\
\text { curricular activities and activities to instill positive values in every activity in the school }\end{array}$ \\
\hline Other & Students' parents in choosing schools with consideration: \\
\hline $\begin{array}{l}\text { Consideration } \\
\text { Factors }\end{array}$ & $\begin{array}{l}\text { - Philosophical foundation in the school in accordance with the community's demand } \\
\text { - A positive image of a school that has been built for a long time }\end{array}$ \\
\hline
\end{tabular}

\section{Conclusion and Recommendation}

The strain S. prasinopilosus Pn-TN2 which isolated from termite nest sample, showed a broad range of antimicrobial activity against bacterial and fungal test. Result showed that this isolate possessed inhibition rate antifungal activity by $80 \%$ against $F$. oxysporum, $61 \%$ against $F$. palustris, and $62 \%$ against $T$. viridae. Advised, this isolate also possessed high antibacterial activity against $B$. subtilis, $P$. aeroginosa, and E. coli. Sequence analysis of $16 \mathrm{~S}$ rRNA gene indicated that isolate Pn-TN2 belongs to genus Streptomyces. It shares $99 \%$ similarity with $S$. prasinopilosus. We conclude that termite nest represent source of cultivable Actinomycetes that contribute diverse bio active compounds for further biotechnology application in the medical, pharmaceutical, and agricultural fields.

\section{Acknowledgment}

We express our gratitude to all our colleagues from the Educational Management Postgraduate Program at Universitas Lambung Mangkurat. In addition to our colleagues, we also sincerely thank our best instructor Dr.
Dalle Juhriyansyah. His guidance really helped us while writing the article. We are very grateful having an instructor and mentor who is patient in giving direction to our writing.

\section{References}

Adebayo, F. A. (2009). Parents' Preference for Private Secondary Schools in Nigeria. International Journal of Education Science, 1(1), 1-6.

Akhter, N. (2017). Factors Affecting Parents' Inclination towards Private School System in Pakistan. Journal of Elementary Education, 27(2), 49-69.

Alamsyah, Aslamiah, \& Rizalie, M. (2019). School based management implementation to improve school quality of multi sites study in SDN alalak selatan 2 dan SDN alalak selatan 4 Banjarmasin city. International Journal of Scientific Development and Research, 4(1), 2455-2631.

Allen, J., Gregory, A., Mikami, A., Lun, J., Hamre, B., \& Pianta, R. (2013). Observations of effective teacher-student interactions in secondary school classrooms: Predicting student achievement with the classroom assessment scoring system-secondary. School Psychology Review, 42(1), 76-98.

Aslamiah. (2015). Hubungan kepemimpinan transformasional kepala sekolah, kepuasan kerja, komitmen organisai, dan organizational citizenship behavior (OCB) dengan kinerja 
guru sekolah dasar negeri di kota banjarmasin. Malang: Program Studi Manajemen Pendidikan Pascasarjana Universitas Negeri Malang.

Baharuddin, \& Dalle, J. (2019). Transforming Learning Spaces for Elementary School Children with Special Needs. Journal of Social Studies Education Research, 10(2), 44-365.

Bambaeeroo, F., \& Shokrpour, N. (2017). The impact of the teachers' non-verbal communication on success in teaching. Journal of Advances in Medical Education \& Professionalism, 5(2), 51-59.

Blazar, D., \& Kraft, M. A. (2017). Teacher and teaching effects on students' attitudes and behaviors. Educational Evaluation and Policy Analysis, 146-170.

Bosetti, L. (2004). Determinants of school choice: Understanding how parents choose. Journal of Education Policy, 19(4), 387-405. doi:10.1080/0268093042000227465

Burgess, S., Greaves, E., Vignoles, A., \& Wilson, D. (2014). What parents want: School preferences and school choice. The Economic Journal, 125, 1262-1289. doi:10.1111/ecoj.12153

Cheryan, S., Ziegler, S. A., Plaut, V. C., \& Meltzoff, A. N. (2014) Designing classrooms to maximize student achievement. Policy Insights from the Behavioral and Brain Sciences, 1(1), 4-12. doi:https://doi.org/10.1177/2372732214548677

Cornell, D. G., \& Mayer, M. J. (2010). Why do school order and safety matter? Educational Researcher, 39(1), 7-15. doi:10.3102/0013189X09357616

Dalle, J., Hadi, S., Baharuddin, \& Hayati, N. (2017). The Development of Interactive Multimedia Learning Pyramid and Prism for Junior High School Using Macromedia Authorware. TOJET: The Turkish Online Journal of Educational Technology, 2017(Special Issue), 714-722.

Darling-Hammond, L. (2000). Teacher quality and student achievement: A review of state policy evidence. Education Policy Analysis Archives, 8(1), 1-44.

David, F. R. (2011). Strategic Management Manajemen Strategi Konsep (12th ed.). Jakarta: Salemba Empat.

Ertas, N. (2013). Charter Schools and Student Compositions of Traditional Public Schools. SAGE Open, 2013, 1-13. doi:https://doi.org/10.1177/2158244013494207

Hafen, C. A., Hamre, B. K., Allen, J. P., Bell, C. A., Gitomer, D. H., \& Pianta, R. C. (2015). Teaching through interactions in secondary school classrooms: Revisiting the factor structure and practical application of the classroom assessment scoring system-secondary. The Journal of Early Adolescence, 35(5-6), 651-680. doi:10.1177/0272431614537117.

Hemelt, S. W., \& Marcotte, D. E. (2011). The Impact of Tuition Increases on Enrollment at Public Colleges and Universities. Educational Evaluation and Policy Analysis, 33(4), 215-229. doi:10.3102/0162373711415261
Ibe, E., \& Abamuche, J. (2019). Effects of audiovisual technological aids on students' achievement and interest in secondary school biology in Nigeria. Heliyon, 5(2019), e01812. doi:https://doi.org/10.1016/j.heliyon.2019.e01812

Kiany, G. R., \& Shayestefar, P. (2011). High school students' perceptions of EFL teacher control orientations and their English academic achievement. British Journal of Educational Psychology, 81(3), 491-508. doi:https://doi.org/10.1348/000709910X522177

Koski, A., Strumpf, E. C., Kaufman, J. S., Frank, J., Heymann, J., \& Nandi, A. (2018). he impact of eliminating primary school tuition fees on child marriage in sub-Saharan Africa: A quasi-experimental evaluation of policy changes in 8 countries. Plos One, 13(5), e0197928. doi:https://doi.org/10.1371/journal.pone.0197928

Kotler, P., \& Amstrong, G. (2018). Principles of Marketing. London: Pearson Education Limited.

Lumpkin, R. B., Jr., R. T., Hope, W. C., \& Lutfi, a. G. (2014). Code Compliant School Buildings Boost Student Achievement. SAGE Open, 2014, 1-8. doi:https://doi.org/10.1177/2158244014556993

Maangi, E. N. (2014). Factors Influencing Parental Patronage of Private Primary Schools in Kenya Despite Free Primary Education (FPE) in Public Schools. Journal of Education and Practice, 5(26), 119-128.

Mahler, D., Großschedl, J., \& Harms, U. (2018). Does motivation matter? - The relationship between teachers' self-efficacy and enthusiasm and students' performance. Plos One, 13(11), doi:https://doi.org/10.1371/journal.pone.0207252

Martin, D. P., \& Rimm-Kaufman, S. E. (2015). Do student selfefficacy and teacher-student interaction quality contribute to emotional and social engagement in fifth grade math? Journal of School Psychology, 53(5), 359-373. doi:https://doi.org/10.1016/j.jsp.2015.07.001

Moleong, L. J. (2007). Metodologi Penelitian Kualitatif (Qualitative Research Method). Bandung: PT. Remaja Rosdakarya Offset.

Mustafa, S. A.-A., Sellami, A. L., Elmaghraby, E. A., \& Al-Qassass, H. B. (2018). Determinants of college and university choice for high-school students In Qatar. International Journal of Higher Education, 7(3), 1-16. doi:10.5430/ijhe.v7n3p1

Normianti, H., Aslamiah, \& Suhaimi. (2019). Relationship of transformational leaders of principal, teacher motivation, teacher organization commitments with performance of primary school teachers in labuan amas selatan, Indonesia. European Journal of Education Studies, 5(11), 2501-1111.

Ntibi, J. E.-E., \& Edoho, E. A. (2017). Influence of school location on students attitude towards mathematics and basic science. British Journal of Education, 5(10), 76-85. 
O’Brennana, L. M., Bradshawa, C. P., \& Furlong, M. J. (2014). Influence of classroom and school climate on teacher perceptions of student problem behavior. School Mental Health, 6(2), 125-136. doi:10.1007/s12310-014-9118-8

Poernamawijaya, L. W., Sulaiman, S., Suriansyah, A., \& Dalle, J. (2018). Contribution on supervision of supervisor, principals motivation, kindergarten teacher performance to improving the kindergarten quality in west Banjarmasin, Indonesia. European Journal of Alternative Education Studies, 3(2), 129-146. doi:doi: 10.5281/zenodo.2261031

Pöysä, S., Vasalampi, K., Muotka, J., Lerkkanen, M.-K., Poikkeus, A.M., \& Nurmi, J.-E. (2019). Teacher-student interaction and lower secondary school students' situational engagement. British Journal of Educational Psychology, 89(2), 374-392. doi: https://doi.org/10.1111/bjep.12244

Premo, J., Cavagnetto, A., Davis, W. B., \& Brickman, P. (2018). Promoting Collaborative Classrooms: The Impacts of Interdependent Cooperative Learning on Undergraduate Interactions and Achievement. CBE Life Sciences Education, 17(2), ar32. doi:https://doi.org/10.1187/cbe.17-08-0176

Ramli, A., \& Zain, R. M. (2018). The impact of facilities on student's academic achievement. Science International, 30(2), 299-311.

Rico-Briones, E., \& Bueno, D. C. (2019). Factors affecting the decision of first year students in choosing their degree program and school. Institutional Multidisciplinary Research and Development Journal, 2, 130-135. doi:10.13140/RG.2.2.25060.01921

Sharma, A., \& Tripathi, V. N. (2016). Factors affecting enrolment trends in government and private schools at elementary level as perceived by teachers and parents. Scholarly Research Journal for Interdiciplinary Studies, 4(27), 31893198.

Shen, B., McCaughtry, N., Martin, J., Garn, A., Kulik, N., \& Fahlman, M. (2015). The relationship between teacher burnout and student motivation. British Journal of Educational Psychology, 85(4), 519-532. doi: https://doi.org/10.1111/bjep.12089

Suhaimi, \& Khalik, A. (2018). Kepemimpinan transformasional kepala sekolah pada SMP 4 muhammadiyah. Jurnal Penelitian Tindakan dan Pendidikan, 4(1), 37-46.

Suhaimi, \& Nuryadin, E. (2018). Hubungan peran kepala sekolah dan sikap terhadap profisi guru dengan prestasi kerja guru SMA negeri di kabupaten hulu sungai selatan. LENTERA Jurnal Ilmiah Kependidikan, 13(1), 73 - 83.

Suppramaniam, S., Kularajasingam, J., \& Sharmin, N. (2019). Factors Influencing Parents Decision in Selecting Private Schools in Chittagong City, Bangladesh. International
Journal of Recent Technology and Engineering, 7(5S), 318330.

Suriansyah, A., \& Aslamiah. (2018). Strategi kepemimpinan kepala sekolah, guru, orang tua, dan masyarakat dalam membentuk karakter siswa. Banjarmasin: Universitas Lambung Mangkurat.

Suriansyah, A., Aslamiah, \& Sulaiman. (2014). Strategi pembelajaran (Teaching strategy). Jakarta: Raja Grafindo Persada.

Thanerajah, V. R., \& Razilan, R. B. (2017). FACTORS THAT INFLUENCE PARENTS ON Choosing international private schools ahead of government schools in Malaysia. International Journal of Accounting \& Business Management, 5(1), 111-128. doi:24924/ijabm/2017.04/v5.iss1/111.128

Wasito, H. (1992). Pengantar Metodologi Penelitian: Buku Panduan Mahasiswa (Introduction to Research Methodology: Student Handbook). Jakarta: PT. Gramedia Pusaka Utama.

Webster-Stratton, C., Jamila Reid, M., \& Stoolmiller, M. (2008). Preventing conduct problems and improving school readiness: evaluation of the Incredible Years Teacher and Child Training Programs in high-risk schools. Journal of Child Psychology and Psychiatry, and Allied Disciplines, 49(5), 471-488. doi:https://doi.org/10.1111/j.14697610.2007.01861.x

Wilkins, S., Shams, F., \& Huisman, J. (2013). The decision-making and changing behavioural dynamics of potential higher education students: the impacts of increasing tuition fees in England. Educational Studies, 39(2), 125-141. doi:https://doi.org/10.1080/03055698.2012.681360

Williams, S., Schneider, M., Wornell, C., \& LanghinrichsenRohling, J. (2018). Student's perceptions of school safety: It is not just about being bullied. The Journal of School Nursing, 20(10), 1-12. doi:10.1177/1059840518761792

Yaacob, N. A., Osman, M. M., \& Bachok, S. (2015). An assessment of factors influencing parents' decision making when choosing a private school for their children: a case study of Selangor, Malaysia: for sustainable human capital. Procedia Environmental Sciences, 28(1), 406- 417. doi:10.1016/j.proenv.2015.07.050

Zeithaml, V., Bitner, \& Gremler. (2013). Service MarketingIntegrating Customer Focus Across The Firm. New York: McGrawHill. 